\title{
JOHN OR PAUL? WHO WAS POLYCARP'S MENTOR?
}

\author{
Kenneth Berding
}

\begin{abstract}
Summary
In some of the patristic writings, Polycarp of Smyrna is explicitly linked with the Apostle John. These writings also include the implication that he was taught by John or installed in his office by John. In contrast (or seemingly), there is a substantial literary (and to a lesser degree, theological) connection to the Apostle Paul in the only surviving letter written by Polycarp himself. The question that concerns us in this study is as follows: Should Polycarp be viewed as standing in the tradition of the Apostle John, as he has been viewed throughout church history, or should he be viewed as standing in the tradition of the Apostle Paul, as one might suppose simply by reading the letter Polycarp himself wrote?
\end{abstract}

\section{Introduction}

One of the most important figures in the history of Christianity in Asia Minor is Polycarp. In the heart of modern-day Izmir (formerly Smyrna) sits a church bearing the name of this famous Christian who was martyred as an elderly man in the stadium of Smyrna shortly after the middle of the second century AD. His importance in early Christian history is widely recognised. Koester says that Polycarp is 'doubtlessly the most significant ecclesiastical leader of the first half of II CE.'. ${ }^{1}$ Torrance refers to Polycarp as 'the most venerable of the Apostolic Fathers, and perhaps the chief depository of the primitive Gospel

1 Helmut Koester, History and Literature of Early Christianity, vol. 2: Introduction to the New Testament (Philadelphia: Fortress and Berlin: Walter de Gruyter, 1982): 308. 
tradition'.2 R. Grant comments, 'The importance of Polycarp of Smyrna for the study of early Christian life in [sic] second century cannot easily be overestimated.' 3

\section{Sources}

Despite Polycarp's importance, there is still relatively little that we know about him. ${ }^{4}$ There are only a few sources that contain accurate historical reflections on Polycarp's life. One of these is the document of his mid-second century martyrdom, The Martyrdom of Polycarp (Mart. Pol.). ${ }^{5}$ We learn the most about Polycarp from a letter (letters?) that he wrote from Smyrna to the church in Philadelphia early in the second century (Pol. Phil.). ${ }^{6}$ There also exists a letter written to him by Ignatius of Antioch while Ignatius was en route to Rome to face almost certain martyrdom (Ign. Pol.) some time before the writing of Polycarp's own letter. ${ }^{7}$ The writings of Irenaeus (d. 202), Tertullian (d.

2 Thomas F. Torrance, The Doctrine of Grace in the Apostolic Fathers (n.p.: Oliver and Boyd Ltd, 1948; repr. Pasadena: WIPF \& Stock Publishers, 1996): 90.

3 Robert M. Grant, 'Polycarp of Smyrna', Anglican Theological Review 28 (1948): 137.

4 'Of the real Polycarp, we know very little-far too little to satisfy our interest, though somewhat more than is known of any eminent Christian from the age of the Apostles to the close of the second century'. J. B. Lightfoot, The Apostolic Fathers: Clement, Ignatius, and Polycarp (part 2, vol. 1; London: Macmillan and Co., 1890; repr., Peabody, Mass.: Hendrickson Publishers, 1989): 436.

5 The date of Polycarp's martyrdom has been widely discussed. I prefer to follow Hartog's suggestion that we 'leave the date somewhere between 155 and 167'. Hartog, Polycarp and the New Testament, WUNT 2.134 (Tübingen: Mohr Siebeck, 2002): 31. See his excellent review of the various approaches to dating Polycarp's martyrdom on pp. 22-32, including his own suggestion of a new date, 23 February AD 161.

6 There is a good possibility that Polycarp's letter to the Philippians is actually one long letter, chs. 1-12 (plus perhaps ch. 14) and another short cover letter for the collection of the letters of Ignatius, ch. 13 (or 13+14). This was suggested first by P. N. Harrison, Polycarp's Two Epistles to the Philippians (Cambridge: CUP, 1936). I basically agree with Harrison's conclusions, but think that his date of AD 135 is too late for the dating of chs. 1-12. I prefer a date of AD 120. See my discussion in Kenneth Berding, Polycarp and Paul: An Analysis of their Literary and Theological Relationship in light of Polycarp's Use of Biblical and Extra-biblical Literature (Supplements to Vigiliae Christianae 62; Leiden: Brill, 2002): 13-24. Henceforth, when the word 'letter' is used in reference to Polycarp's letter to the Philippians (Pol. Phil.) it will be a reference only to chs. 1-12 of the letter as we now have it.

7 Ignatius also wrote a letter to the church in Smyrna, which helps a little to fill out the social situation of the Christians in Smyrna early in the second century. As to the date, most scholars agree that Ignatius was martyred during Trajan's reign (AD 98117 ), and thus wrote his letters some time during that period. More precision than this is difficult. 
220), Eusebius (d. 339), and Jerome (d. 420) all contain historical reminiscences; though in the case of the last three, it seems that they are at least mostly dependent upon the statements made by Irenaeus. Finally, there are the Harris Fragments published by Weidmann ${ }^{8}$ that may add a few pieces of information to our general understanding of Polycarp. ${ }^{9}$

\section{The Problem}

The problem that concerns us in this study is that there is an explicit historical link to the Apostle John in some of these traditions (including those of Irenaeus, Tertullian, Eusebius, Jerome and the Harris Fragments) which includes the implication that Polycarp was taught or installed in his office by John. ${ }^{10}$ In contrast (seemingly), there is a substantial literary (and to a lesser degree, theological) connection to the Apostle Paul in the only surviving letter written by Polycarp himself (Pol. Phil.). Thus, the question begging to be asked is this: Should Polycarp be viewed as standing in the tradition of the Apostle John, as he has been viewed throughout church history, or should he be viewed as standing in the tradition of the Apostle Paul, as one might suppose simply by reading the letter Polycarp himself wrote? ${ }^{11}$

8 Frederick W. Weidmann, Polycarp \& John: The Harris Fragments and Their Challenge to the Literary Traditions (Notre Dame: University of Notre Dame Press, 1999).

9 Note that the Life of Polycarp, purportedly by Pionius, is too problematic to use in a historical analysis of the life of Polycarp because of problems associated with its dating, use of anachronisms, and legendary-texture. Lightfoot, The Apostolic Fathers $2: 1,435-36$ says of this document, 'If it contains any grains of truth, we have no means of sifting them from the huge heap of falsehood'. For an analysis of this document in its own historical setting, see Alistair Stewart-Sykes, The Life of Polycarp: An Anonymous Vita from third-century Smyrna (Sydney: St. Pauls, 2002).

10 Irenaeus, Haer. 3.3.4 [Hist. eccl. 5.20]; Tertullian, Praescr. 32.2; Eusebius, Hist. eccl. 4.14; Jerome, Vir. ill. 17; FrgPol (cf. Weidmann, Polycarp \& John).

11 D. Richard Stuckwisch in his article 'Saint Polycarp of Smyrna: Johannine or Pauline Figure?' Concordia Theological Quarterly 61 (1997): 113-25 took up a similar discussion with a different evaluation of the evidence. 


\section{Sifting the Evidence: A Connection to John?}

As has just been mentioned, Tertullian, Eusebius, Jerome, and probably FrgPol in the Harris Fragments ${ }^{12}$ make an explicit connection between the persons of Polycarp and John the Apostle. But it is likely that the traditions found in Tertullian, Eusebius, and Jerome are, at least at most points, dependent on the testimony of Irenaeus (Haer. 3:3:4; Eusebius, Hist. eccl. 5:20) who wrote toward the end of the second century AD. Irenaeus says that he personally had heard Polycarp tell of conversations "with John and with the rest of those who had seen the Lord...' (Hist. eccl. 5:20), though he does not explicitly refer to John as an apostle. Elsewhere, Irenaeus says that 'Polycarp also was not only instructed by apostles, and conversed with many who had seen Christ, but was also, by apostles in Asia, appointed bishop of the Church in Smyrna...' (Haer. 3:3:4). Though Irenaeus claims that Polycarp was appointed bishop by the apostles, in this passage he does not limit the source of that appointment to John.

The lack of clarity in these statements, coupled with Irenaeus's evident desire to employ Polycarp as a living link to the apostolic age in his apologetic arguments, has led many scholars to question whether Polycarp ever in fact was associated with the Apostle John. ${ }^{13}$ Often, what is suggested is that the 'John' of whom Irenaeus wrote was not the Apostle John, but was another John-'John the Elder'-whom Papias mentions (Eusebius, Hist. eccl. 3:39:4) and that Irenaeus was mistaken in making such a connection (a connection only intensified by those after him $^{14}$ ). A detailed look at the language of Irenaeus and

12 See discussion of this issue in Weidmann, Polycarp \& John: 67-73 who, after sifting the evidence, concludes that the 'apostle' who is mentioned in this document is probably the Apostle John rather than Paul or someone else.

13 E.g. Pierre Nautin, Lettres et Écrivains Chrétiens des IIe et IIIe Siècles (Paris: Cerf, 1961): 82 n. 2 and 92; J. N. Sanders, The Fourth Gospel in the Early Church: Its Origin \& Influence on Christian Theology up to Irenaeus (Cambridge: CUP, 1943); Richard J. Bauckham, 'Papias and Polycrates on the Origin of the Fourth Gospel', JTS 44 (1993): 24-69; Paul Trebilco, The Early Christians in Ephesus from Paul to Ignatius (Tübingen: Mohr Siebeck, 2004): 242-58. Arguments for what appears to be the minority view, that there was no John the Elder and that the connections are to the Apostle John, see C. Stewart Petrie, 'The Authorship of "The Gospel according to Matthew": A Reconsideration of the External Evidence', NTS 14 (1967): 15-27; Leon Morris, The Gospel according to John, rev. ed. (Grand Rapids: Eerdmans, 1995): 4-24 (esp. 20-24); D. A. Carson, Douglas Moo and Leon Morris, An Introduction to the New Testament (Grand Rapids, Mich.: Zondervan, 1992): 139-43.

14 Hartog, Polycarp and the New Testament: 41 comments that the further chronologically one goes from Polycarp, moving from Irenaeus to Tertullian, to the 
Papias (and at Eusebius's interpretation of Papias) would overwhelm the rest of this discussion, but I will state at this point that I think that this particular question may remain unresolved unless other ancient documents come to light. I am not convinced that it can be certainly known either that Polycarp had personal contacts with the Apostle John, ${ }^{15}$ or that he had contact with a certain John the Elder (if such a person ever actually existed). There does not seem to be enough independent material either to collaborate or to dismiss the testimony of Irenaeus (and those that follow him) on this point. ${ }^{16}$

Perhaps clearer evidence of some level of Johannine influence is found in the Martyrdom of Polycarp which appears to have some points of contact with the passion narrative recorded in the Gospel of John. If eyewitnesses from the church in Smyrna were literarily dependent on the Gospel of John shortly after the death of Polycarp, this could suggest (even if slightly) some sort of Johannine influence on the church of Smyrna, and presumably upon its most famous Christian. ${ }^{17}$

Moreover, there are unmistakable literary connections to 1 John in Polycarp's own letter (Pol. Phil. 7:1). This small paragraph notably contains a compressed citation of 1 John 4:2-3, a probable allusion to 1 John 3:8 and possible reminiscences of 1 John 5:6-9 and 1 John 3:12. ${ }^{18}$ These alone, though, are inadequate to categorise Polycarp as primarily in a Johannine stream or even to substantiate a personal relationship between Polycarp and John the Apostle. Furthermore, the

Harris Fragments, to Eusebius, and to Jerome, 'one notices a development toward a closer connection between John and Polycarp which stresses Episcopal ordination and apostolic succession... Over a period of time, the retelling of the association may have grown into apostolic ordination.'

15 It is interesting that Irenaeus does not say Polycarp was taught by John (an interesting omission since it would have helped his argument) but that John lived in Ephesus until the time of Trajan, thus implying that Polycarp would have been acquainted with him.

16 The exception could be the FrgPol in the Harris Fragments which may be independent of direct influence from Irenaeus, but still appears to be 'breathing the air' of apologetic arguments for apostolic succession.

17 E.g. W. von Loewenich, Das Johannes Verständnis im zweiten Jahrhundert (ZNWBeih 13; Giessen: Alfred Töpelmann, 1932): 23-24; Hengel, The Johannine Question (London: SCM, 1989; tr. John Bowden): 5; note further suggestions for Johannine allusions in Mart. Pol. in Charles E. Hill, The Johannine Corpus in the Early Church (Oxford: OUP, 2004): 358-59.

18 Cf. Berding, Polycarp and Paul: 88-91. 
lack of any clear connections to the Gospel of John in a letter packed full of allusions to other Christian literature is noteworthy. ${ }^{19}$

\section{A Connection to Paul?}

Contrasting the case of Polycarp's connections to John, there are no ancient sources that connect the person or writings of Paul to Polycarp. Rather, this side of the argument comes primarily from Polycarp's own literary activity.

Polycarp's letter to the Philippians offers substantial literary and theological evidence that Polycarp was strongly influenced by Pauline writings and themes in the composition of his letter, to the point that it could be argued (as I have argued elsewhere) that Polycarp is imitating both a Pauline style and Paul's ethical example. ${ }^{20}$

Almost half of all references to earlier literature in Polycarp's Philippians are from the letters of Paul. ${ }^{21}$ Polycarp mentions Paul's name in three different chapters, once each in chapters 3 and 9 and twice in chapter 11. Each time Polycarp mentions Paul's name, he clusters quotations from and allusions to Paul around the mention of Paul's name. ${ }^{22}$ Polycarp does not refer to any other apostle by name. ${ }^{23}$ He connects with many of Paul's theological themes, particularly those that emerge in Paul's ethical teaching. ${ }^{24}$ In short, Polycarp's

19 Charles E. Hill, The Johannine Corpus: 416-20, argues for echoes of John 13:34 in Pol. Phil. 10.1 ('lovers of the brotherhood'); of John 6:40, 44, and 54 in Pol. Phil. 5.2 ('he promised to raise us from the dead'); of John 19:34-35 in Pol. Phil. 7.1 (together with 1 John 4:2-3 water and blood); of John 8:44 in Pol. Phil. (together with 1 John 3:8 'of the devil'). But the proposed allusions to John 13:34 and John 6:40, 44, and 54 would both have been stock Christian language and cannot be demonstrably connected to these particular passages, and the proposed allusions to John 19:34-35 and John 8:44 are better explained by the more obvious dependency upon 1 John $(4: 2-3$ and $3: 8$ respectively).

20 Charles E. Hill, The Johannine Corpus: 126-41.

21 For a detailed discussion of each possible quotation, allusion and reminiscence in Pol. Phil., see Berding, Polycarp and Paul: 33-125.

22 Berding, Polycarp and Paul: 142-55; Kenneth Berding, 'Polycarp's View of the Authorship of 1 and 2 Timothy', Vigiliae Christianae 53 (1999): 349-60.

23 Though he does mention the martyrs Ignatius, Zosimus and Rufus in Pol. Phil. 9.1.

24 Berding, Polycarp and Paul: 156-86. See also Peter Oakes, 'Leadership and Suffering in the Letters of Polycarp and Paul to the Philippians' in Trajectories through the New Testament and the Apostolic Fathers, ed. Andrew F. Gregory and Christopher M. Tuckett (Oxford: OUP, 2005): 353-73. 
Philippians shows evidence throughout of a substantial dependence upon Paul.

The letters of Ignatius to Polycarp and to the church in Smyrna do not add much to our understanding of whether Polycarp was in a Johannine stream or in a Pauline stream. Still, it is interesting to observe the significant influence of Paul upon the writings of Ignatius and the lack of any such literary connection to John in Ignatius. ${ }^{25}$

\section{An Evaluation}

On the one hand, there are some indications of literary and thematic connections to John both by Polycarp himself (connections to 1 John in Pol. Phil. 7:1) and from the church in Smyrna shortly after his death (connections to the Gospel of John in Mart. Pol.), though these connections are not sufficient to support the view that Polycarp was a disciple who was trained by the Apostle John. Furthermore, ecclesiastical writings after the time of Polycarp (which are mostly dependent upon Irenaeus) that imply or directly say that Polycarp was taught by the Apostle John are not unambiguous enough to argue (as has usually been assumed throughout history) that Polycarp was primarily influenced by John.

On the other hand, there are clear literary and thematic connections to Paul in Polycarp's Philippians. These connections are strong enough that one is tempted simply to pronounce that Polycarp is primarily influenced by Paul. ${ }^{26}$ But there are other considerations to take into account which might speak against any primary connection either to Paul or to John. These may in the end guide us toward at least a partial solution.

25 Andreas Lindemann, 'Paul in the Writings of the Apostolic Fathers' in Paul and the Legacies of Paul, ed. William S. Babcock (Dallas: Southern Methodist University Press, 1990): 40 comments, 'Ignatius, we might say, was making an entirely unforced use of Paul, implicit rather than explicit, without rather than with any special thought or attention. If this view is correct, however, the allusions to Paul are all the more remarkable; they demonstrate just how far-reaching the Pauline influence on Ignatius apparently was.' Of course, the use of Paul and lack of use of John could be merely an issue of dating, since the Johannine materials may not have had much time to circulate by the time he wrote just after the turn of the second century.

26 Cf. Charles M. Nielsen, 'Polycarp, Paul and the Scriptures', Anglican Theological Review 47 (1965): 199-216 and 'Polycarp and Marcion: A Note', Theological Studies 47 (1986): 297-99. 
First, it is likely that the primary reason that there is such a pronounced dependence upon Paul in Polycarp's Philippians is that Polycarp is writing to a church founded by the Apostle Paul. In light of the fact that Philippians is Polycarp's only extant writing, we simply do not know whether Polycarp would have shown the same regard for Paul if he had been writing to a church founded by another apostle.

Second, Polycarp draws regularly upon the letter of 1 Peter in Philippians. Of course, when compared with the frequency with which he quotes from the letters of Paul, his employment of 1 Peter is significantly less. Still there exist five almost certain citations of 1 Peter, six probable citations or allusions to 1 Peter, and three other references that should be considered possible literary connections to 1 Peter. ${ }^{27}$ In addition, there is one almost certain loose citation of Acts 2:24 in Polycarp's Philippians 1:2.28 These oblige us to move away from claims that Polycarp can be placed under any single authority or in any single theological stream.

Third, Polycarp shows explicitly (in Pol. Phil. 6:3) that he draws upon three main streams of authority. ${ }^{29}$ 'So, then, let us serve him [i.e. Christ] with fear and all reverence, just as he himself has commanded, as did the apostles, who preached the gospel to us, and the prophets, who announced in advance the coming of our Lord'.

Stream of authority \#1 is the words and example of the Lord. Polycarp appears to use, at the same time, written Gospels (both Matthew and Luke) and still be dependent upon the sayings of the Lord mediated orally. ${ }^{30}$

Stream of authority \#2 is the Old Testament prophets. Polycarp thinks of the Old Testament writings as a whole as the 'Sacred Scriptures' (Pol. Phil. 12:1). He evinces probable literary connections to the Psalms, Proverbs, Isaiah, Jeremiah, and possibly to Ezekiel.

Stream of authority \#3 consists of the apostolic writings. In Polycarp's use, this is primarily the letters of Paul, secondarily 1 Peter,

27 Berding, Polycarp and Paul: 201-2 and the analysis of each possible connection in ch. 2. Eusebius (Hist. eccl. 4.14.9) actually comments on Polycarp's frequent use of 1 Peter in Pol. Phil.

28 In this regard, there are also some probable literary connections to 1 Clement, though Polycarp appears not to cite 'Clement' with the same authority that he cites the apostles. See Berding, Polycarp and Paul: 162, 202. There also appears to be a clear connection to Tobit 4:10 and/or 12:9 in Pol. Phil. 10.2.

29 See discussion in Berding, Polycarp and Paul: 158-62.

30 See extended discussion of Pol. Phil. 2.2-3 in Berding, Polycarp and Paul: 48-59. 
and thirdly 1 John, though allusions to other apostolic writings are likely.

\section{Conclusion}

Who was Polycarp's 'mentor'? Are we now in a position to answer the question of who had the greatest influence on Polycarp? In one sense the answer to this question is still negative. We still do not know whether Polycarp was primarily Pauline, primarily Johannine, or primarily anything. The evidence available to us is inadequate to answer this particular question. Still, although this particular question may not be answerable, our analysis allows us to dispense of one contrary notion. Polycarp is not merely in a stream of any one apostle or another. He is willing to draw from any of a number of different streams of God-given authority, including a Pauline stream, a Petrine stream, a Johannine stream, the words of the Lord (both in oral and written form), and the Old Testament Scriptures. His writings clearly demonstrate that he understands himself to be in continuity with these authorities, not opposed to any of them.

So as we evaluate the relationship of Polycarp to those who came before him-Polycarp, who gave his life for what he believed-we need to remember that he was willing to go to his death neither because he was merely a disciple of John, nor because he was merely a student

of Paul, but because he was a follower of Christ as taught in the apostolic tradition. 